\title{
Review Article \\ Impact of KRAS Mutations on Management of Colorectal Carcinoma
}

\author{
Kevin M. Sullivan and Peter S. Kozuch \\ Department of Medicine, Section of Hematology/Oncology, Albert Einstein College of Medicine, \\ Beth Israel Medical Center, Phillips Ambulatory Care Center, 10 Union Square East, Suite 4C, \\ NY 10003, USA
}

Correspondence should be addressed to Peter S. Kozuch, pkozuch@chpnet.org

Received 28 September 2010; Revised 2 January 2011; Accepted 10 January 2011

Academic Editor: Wade Samowitz

Copyright ( $) 2011$ K. M. Sullivan and P.S. Kozuch. This is an open access article distributed under the Creative Commons Attribution License, which permits unrestricted use, distribution, and reproduction in any medium, provided the original work is properly cited.

\begin{abstract}
The epidermal growth factor receptor (EGFR) pathway is a therapeutic target in the management of colorectal cancer (CRC). EGFR antagonists are active in this disease; however, only a subset of patients respond to such therapy. A Kirsten ras sarcoma viral oncogene (KRAS) wild-type (WT) status of the tumor is necessary, but possibly not sufficient, for a response to anti-EGFR monoclonal antibody therapy. Mechanisms of primary resistance to such therapy in patients harboring KRAS WT tumors are discussed. Strategies to overcome resistance to anti-EGFR monoclonal antibody therapy, including novel agents and combinations of novel therapies, are explored. Also, the use of anti-EGFR monoclonal antibodies in the adjuvant and neoadjuvant setting is reviewed.
\end{abstract}

\section{Introduction}

Tumor growth and progression depends in part on the activity of cell surface membrane receptors which control signal transduction pathways. These growth factor receptors can have aberrations in their expression and regulation and activation of growth factor pathways is common in many malignancies [1]. The EGFR, a transmembrane glycoprotein also called ERBB-1 or HER1, is a member of a family of receptor tyrosine kinases (TKs). The EGFR is involved in signaling pathways controlling cell growth, differentiation, and proliferation and is expressed in many different types of normal tissues as well as several tumor types, including CRC $[2,3]$. Figure 1 illustrates the main EGFR signaling pathways described [4]. When a ligand binds to the EGFR, the receptor forms a dimer resulting in a signaling cascade within the cell via tyrosine kinase activity [5]. This signaling cascade occurs by the activation of receptor autophosphorylation which triggers a number of intracellular pathways regulating cell proliferation, prevention of apoptosis, and promotion of invasion, metastasis, and neovascularization [6]. The proto-oncogene c-erb-B encodes the EGFR, and activation of the proto-oncogene results in EGFR expression in many tumors [7, 8]. There was therefore interest in investigating this pathway as a potential anticancer therapy target.

Pharmacologically, there are two classes of EGFR antagonists currently in clinical use: antiEGFR monoclonal antibodies directed against the extracellular domain of the receptor and oral small-molecule EGFR TK inhibitors which block the receptor TK activity competitively [10]. The antiEGFR monoclonal antibodies, cetuximab and panitumumab, act by binding to the extracellular region of the EGFR and therefore block the ligand-binding region which prevents ligandinduced TK activation [11]. These monoclonal antibodies solely recognize the EGFR, making them very selective for their target [5]. The small-molecule EGFR TK inhibitors, erlotinib and gefitinib, inhibit the catalytic activity of the TK by competing with adenosine triphosphate (ATP) to bind to the intracellular domain [10]. These small-molecule inhibitors are not exclusive to the EGFR pathway and can block different receptor tyrosine kinases, such as the vascular endothelial growth factor (VEGF) receptor and other members of the EGFR family. 


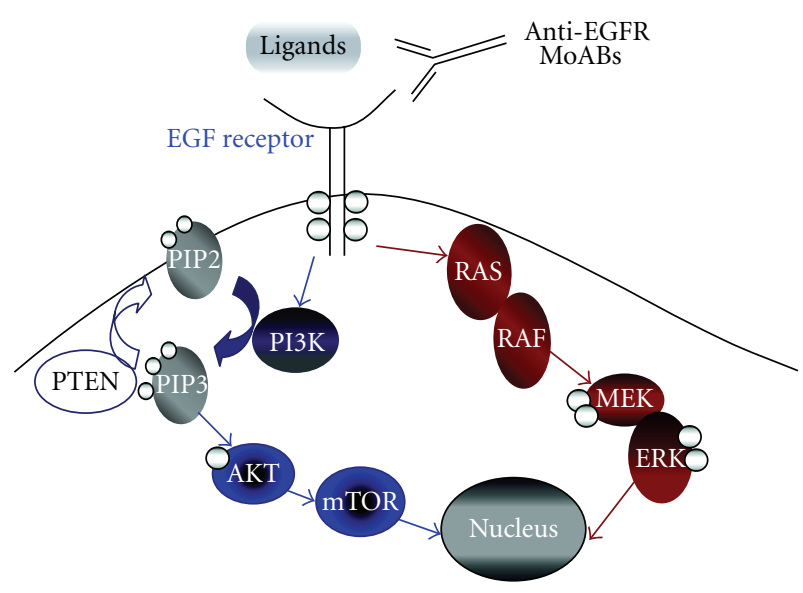

FIGURE 1: EGFR signaling pathway [4]. (Reprinted with permission from American Society of Clinical Oncology 2008. All rights reserved.)

Anti-EGFR monoclonal antibodies have been evaluated in both untreated metastatic CRC and chemotherapy refractory disease. Figure 2 summarizes the current treatment paradigm for metastatic colorectal cancer including the appropriate incorporation of antiEGFR monoclonal antibody therapy which improves survival for appropriately selected patients [9]. Table 1 summarizes selected clinical trials of antiEGFR monoclonal antibodies in metastatic CRC. Response rates with single-agent antiEGFR monoclonal antibodies range from 9-12\%, with much higher response rates observed when cetuximab is used in combination with chemotherapy [12-22]. When administered to unselected metastatic CRC patients, only a minority responded to EGFR inhibitor therapy. Therefore, a method to identify and predict sensitivity to these drugs was needed.

\section{Prediction of Response to Anti-EGFR Monoclonal Antibodies}

The RAS family of proto-oncogenes include HRAS, KRAS, and NRAS [23]. KRAS (Kirsten ras sarcoma viral oncogene) is a guanosine triphosphate-(GTP-) binding protein downstream of the EGFR and is a central component of the mitogen-activated protein kinase (MAPK) pathway, a component of the EGFR signaling cascade [23]. Roughly $40 \%$ of colorectal cancers are characterized by a mutation in the KRAS gene [24]. About $90 \%$ of these mutations occur in codons 12 and 13 in exon 2 of the KRAS gene, with the remaining mutations occurring in codons 61 and 146 (roughly $5 \%$ each) $[25,26]$. Such KRAS mutations lead to EGFR-independent constitutive activation of the signaling pathway and predict for a lack of response and benefit from antiEGFR monoclonal antibodies cetuximab and panitumumab [27-35]. De Roock et al. showed that codon 61 mutations predicted for lack of response to cetuximab similar to codon 12 and 13 mutations; however, codon 146 mutations did not affect cetuximab efficacy [26]. Failure to test for codon 61 mutations may miss a significant mutation which would confer resistance to antiEGFR monoclonal antibody therapy. There is a very high concordance of KRAS mutational status between the primary tumor and metastasis, ranging from $92-100 \%$ [3638]. However, KRAS mutation status heterogeneity between primary tumors, lymph nodes and distant metastases in 5$10 \%$ of patients has been reported, with mixed responses to antiEGFR monoclonal antibody therapy in those with metastatic CRC $[37,39,40]$. Because of this, some clinicians have called for a reassessment of KRAS mutation status on metastatic foci in situations where only the primary tumor was assessed for KRAS status [41].

Table 2 summarizes clinical trials of antiEGFR monoclonal antibodies which included analysis of treatment effect and KRAS mutation status. Amado et al. assessed the predictive role of KRAS mutational status in a randomized phase III trial comparing panitumumab monotherapy with best supportive care (BSC) in patients with chemotherapy refractory metastatic CRC [24]. This trial showed that the clinical benefit associated with panitumumab was restricted to the KRAS WT population. KRAS mutations predicted for lack of clinical benefit to panitumumab [24]. Similarly, Karapetis et al. showed that treatment with cetuximab significantly improved OS and PFS in patients with KRAS WT tumors; however, in this chemotherapy-resistant patient population, those with mutated KRAS tumors did not benefit [38]. Use of cetuximab as first-line treatment for metastatic disease was investigated by Van Cutsem et al.; patients were randomly assigned to receive FOLFIRI with or without cetuximab [36]. A statistically significant benefit in PFS for patients with KRAS WT tumors receiving cetuximab and chemotherapy was confirmed in a final presentation of this trial [42]. Bokemeyer et al. investigated the use of cetuximab in combination with FOLFOX chemotherapy as initial treatment for metastatic disease [34]. A retrospective analysis of this data revealed that cetuximab and chemotherapy had a statistically significant increased response rate and lower risk of disease progression compared with chemotherapy alone in patients with KRAS WT tumors [43]. Prospectively, panitumumab has been investigated with either FOLFOX or FOLFIRI chemotherapy in the first-line metastatic setting $[44,45]$. The addition of panitumumab to FOLFOX chemotherapy was associated with a statistically significant improvement in PFS [44]. Taken together, the data in Table 2 supports that in metastatic CRC, KRAS WT and mutation status predict for potential sensitivity to, and definite resistance to, respectively, both antiEGFR monoclonal antibodies, regardless of prior treatment and irrespective of use as monotherapy or in combination. Notably, while KRAS status is an established predictor of response to antiEGFR monoclonal antibody therapy, it has been disproven as a prognostic marker. In contrast to KRAS mutational status, evaluation of EGFR expression of CRC cells has failed to demonstrate predictive value for antiEGFR monoclonal antibody therapy. Cunningham et al. reported that the intensity of EGFR staining by immunohistochemical analysis did not correlate with response rate to cetuximab [13]. Similar data has also been reported with panitumumab [46]. KRAS mutated CRC absent of antiEGFR monoclonal 


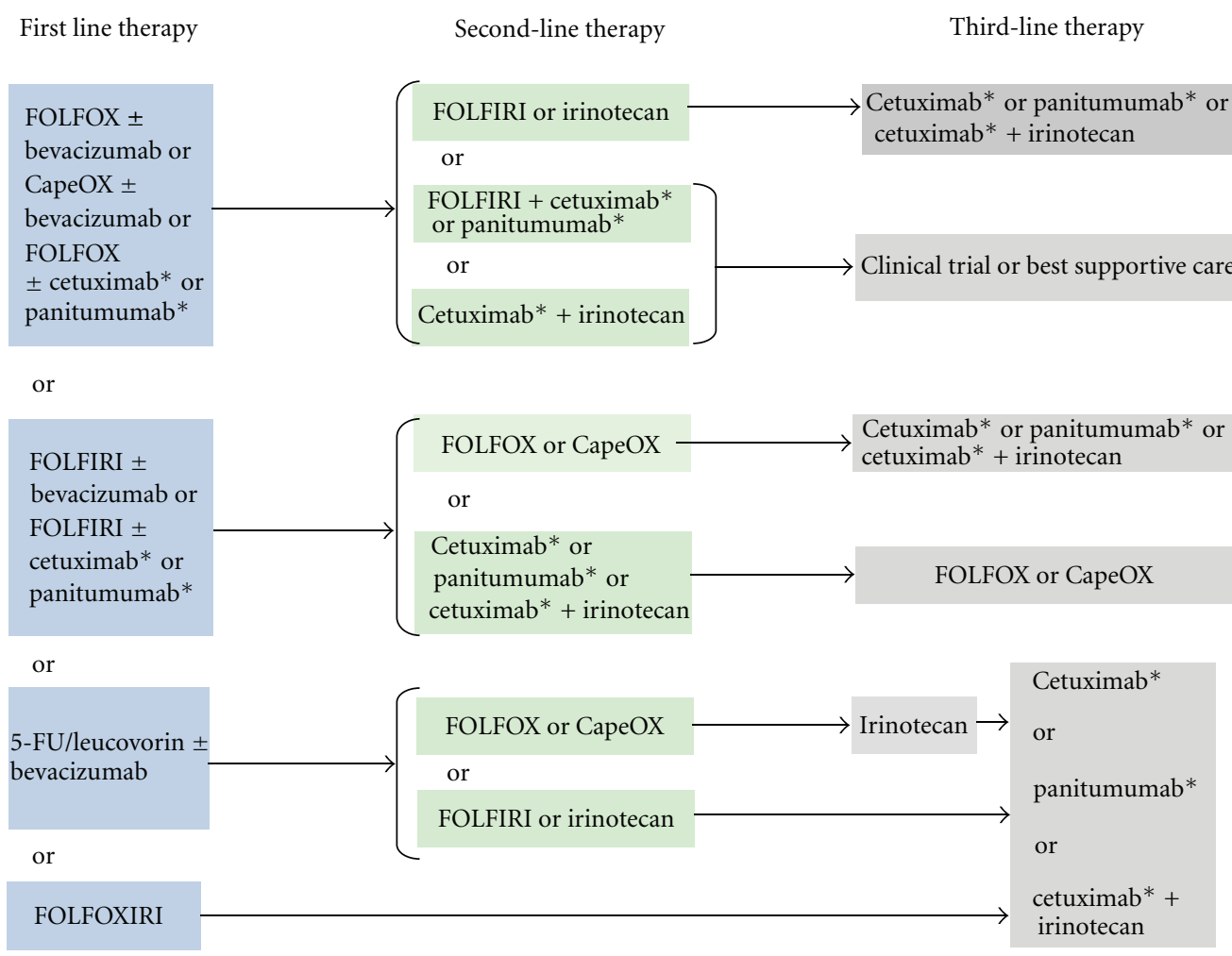

FIGURE 2: The current treatment paradigm for patients with metastatic colorectal cancer who are appropriate for intensive therapy [9]. * For patients with KRAS WT gene only. CapeOX: capecitabine + oxaliplatin.

antibody therapy is not inferior to patients with KRAS WT disease. The evaluation of KRAS mutational status is a mandatory aspect of management of patients at the time of diagnosis of metastatic CRC.

\section{Mechanisms of Resistance}

While KRAS mutations are a major mechanism of primary resistance to antiEGFR monoclonal antibody therapies, resistance mechanisms in KRAS WT patients are also being defined. Forty-sixty percent of patients with KRAS WT tumors fail to respond to treatment with antiEGFR monoclonal antibodies [51]. Therefore, other possible molecular determinants of response are being identified in those patients with EGFR monoclonal antibody-resistant WT KRAS disease.

The importance and frequency of NRAS (a ras oncogene variant) mutations in CRC remains under-investigated $[52,53]$. Lambrechts et al. found that NRAS, KRAS, and BRAF mutations were all mutually exclusive events, with combined WT status of these genes associated with higher response rates and longer progression-free survival times [54]. Lambrechts et al. also reported that an NRAS mutation was associated with a lack of response to cetuximab. Irahara et al. investigated the relationship between NRAS mutations and clinical outcome in a collection of 225 colorectal cancers from two prospective cohort studies [55]. NRAS mutations were detected in $2.2 \%$ of the CRCs. There was no apparent association between the NRAS mutations and any clinical or pathologic features, including patient survival. However, the low frequency of NRAS mutations may obscure a significant relation. De Roock et al. conducted a retrospective analysis of over 700 tumor samples from patients treated with cetuximab plus chemotherapy and found a NRAS mutation frequency of $2.6 \%$. Additionally, in KRAS wild types, carriers of NRAS mutations had a significantly lower response rate to cetuximab than NRAS wild types (7.7\% versus $38.1 \%$, $P=.013$ ) [26]. There was, however, no significant difference in median PFS (14 versus 26 weeks, $P=.055$ ) and median OS (38 versus 50 weeks, $P=.051$ ) between NRAS wild types and mutants [26].

B-type Raf kinase (BRAF) is a component of the RASRAF-MEK signaling cascade of the EGFR (see Figure 1) [56]. A specific mutation in the BRAF gene (V600E) is present in approximately $5-8 \%$ of CRCs and is thought to be limited to those tumors without mutations in exon 2 of KRAS $[42,57]$. BRAF, which is located directly downstream from RAS, can have activating mutations leading to stimulation of the MEK pathway $[56,58]$. BRAF mutations appear to confer a poor prognosis, and it appears that BRAF mutations also predict for a lack of response to antiEGFR monoclonal antibodies $[42,57,59,60]$. Loupakis et al. analyzed 87 patients with KRAS WT tumors for the BRAF V600E mutation who were receiving irinotecan and cetuximab for refractory metastatic 
TABLE 1: Clinical trials of antiEGFR monoclonal antibodies in metastatic CRC.

\begin{tabular}{|c|c|c|c|c|c|c|c|}
\hline Study & Setting & Treatment & No. of patients & ORR (\%) & mTTP (mos) & mPFS (mos) & $\operatorname{mOS}(\mathrm{mos})$ \\
\hline $\begin{array}{l}\text { Single Arm } \\
\text { phase II [12] }\end{array}$ & $\begin{array}{l}\text { Irinotecan- } \\
\text { refractory }\end{array}$ & $\begin{array}{l}\text { Cetuximab } \\
\text { monotherapy }\end{array}$ & 57 & 9 & 1.4 & N.R. & 6.4 \\
\hline $\begin{array}{l}\text { Randomized } \\
\text { phase II [13] }\end{array}$ & $\begin{array}{l}\text { Refractory } \\
\text { disease to 5-FU } \\
\text { and Irinotecan }\end{array}$ & $\begin{array}{l}\text { Cetuximab } \\
\text { monotherapy } \\
\text { vs. Cetuximab + } \\
\text { Irinotecan }\end{array}$ & 111 vs. 218 & $10.8^{*}$ vs. 22.9 & $1.5^{*}$ vs. 4.1 & N.R. & 6.9 vs. 8.6 \\
\hline $\begin{array}{l}\text { Single Arm } \\
\text { phase II [14] }\end{array}$ & $\begin{array}{l}\text { Refractory } \\
\text { disease to 5-FU, } \\
\text { Irinotecan, and } \\
\text { Oxaliplatin }\end{array}$ & $\begin{array}{l}\text { Cetuximab } \\
\text { monotherapy }\end{array}$ & 346 & 12.4 & 1.4 & N.R. & 6.6 \\
\hline $\begin{array}{l}\text { Single Arm } \\
\text { phase II [15] }\end{array}$ & $\begin{array}{l}\text { First-line } \\
\text { treatment }\end{array}$ & $\begin{array}{l}\text { Cetuximab + } \\
\text { Irinotecan + } \\
\text { 5-FU/FA }\end{array}$ & 21 & 67 & 9.9 & N.R. & 33.0 \\
\hline $\begin{array}{l}\text { Randomized } \\
\text { phase III [16] }\end{array}$ & $\begin{array}{l}\text { Refractory } \\
\text { disease to 5-FU, } \\
\text { Irinotecan and } \\
\text { Oxaliplatin }\end{array}$ & $\begin{array}{l}\text { Cetuximab } \\
\text { monotherapy } \\
\text { vs. BSC }\end{array}$ & 287 vs. 285 & $8^{*}$ vs. 0 & N.R. & $1.9^{*}$ vs. 1.8 & $6.1^{*}$ vs. 4.6 \\
\hline $\begin{array}{l}\text { Single Arm } \\
\text { phase II [17] }\end{array}$ & $\begin{array}{l}\text { First-line } \\
\text { treatment }\end{array}$ & $\begin{array}{l}\text { Cetuximab + } \\
\text { FOLFOX-4 }\end{array}$ & 43 & 72 & N.R. & 12.3 & 30 \\
\hline $\begin{array}{l}\text { Randomized } \\
\text { phase III [18] }\end{array}$ & $\begin{array}{l}\text { Refractory to } \\
\text { Oxaliplatin }\end{array}$ & $\begin{array}{l}\text { Cetuximab + } \\
\text { Irinotecan vs. } \\
\text { Irinotecan }\end{array}$ & 648 vs. 650 & $16.4^{*}$ vs. 4.2 & N.R. & $4.0^{*}$ vs. 2.6 & 10.7 vs. 10.0 \\
\hline $\begin{array}{l}\text { Randomized } \\
\text { phase III [19] }\end{array}$ & $\begin{array}{l}\text { First-line } \\
\text { treatment }\end{array}$ & $\begin{array}{l}\text { Cetuximab + } \\
\text { FOLFIRI vs. } \\
\text { FOLFIRI }\end{array}$ & 602 vs. 600 & $46.9^{*}$ vs. 38.7 & N.R. & $8.9 *$ vs. 8.0 & N.R. \\
\hline $\begin{array}{l}\text { Randomized } \\
\text { phase III [20] }\end{array}$ & $\begin{array}{l}\text { Refractory } \\
\text { disease to 5-FU, } \\
\text { Irinotecan and } \\
\text { Oxaliplatin }\end{array}$ & $\begin{array}{l}\text { Panitumumab } \\
\text { monotherapy } \\
\text { versus BSC }\end{array}$ & 231 vs. 232 & $10.0^{*}$ vs. 0 & N.R. & $\begin{array}{c}8 \text { weeks* }^{*} \text { vs. } 7.3 \\
\text { weeks }\end{array}$ & 6.5 vs. 6.5 \\
\hline $\begin{array}{l}\text { Randomized } \\
\text { phase II [21] }\end{array}$ & $\begin{array}{l}\text { Refractory to } \\
\text { Irinotecan }\end{array}$ & $\begin{array}{l}\text { Irinotecan }+ \\
\text { Cetuximab+ } \\
\text { Bevacizumab vs. } \\
\text { Cetuximab + } \\
\text { Bevacizumab }\end{array}$ & 43 vs. 40 & 37 vs. 20 & 7.3 vs. 4.9 & N.R. & 14.5 vs. 11.4 \\
\hline $\begin{array}{l}\text { Single Arm } \\
\text { phase II [22] }\end{array}$ & $\begin{array}{l}\text { Refractory to } \\
\text { Irinotecan }+ \\
\text { Bevacizumab }\end{array}$ & $\begin{array}{l}\text { Cetuximab }+ \\
\text { Bevacizumab }+ \\
\text { Irinotecan }\end{array}$ & 33 & 9 & 3.9 & N.R. & 10.6 \\
\hline
\end{tabular}

${ }^{*}$ Statistically significant improvement.

ORR: overall response rate; mTTP: median time to progression; mPFS: median progression-free survival; mOS: median overall survival; N.R.: not reported; 5-FU: 5-fluorouracil; BSC: best supportive care; FA: folinic acid; NS: not significant.

CRC. This mutation was found in $15 \%$ of the patients and was associated with a lack of response to therapy $(0 \%$ versus $32 \%, P=.016)$ and a shorter overall survival (4.1 months versus 13.9 months, $P=.037$ ) [61]. An additional retrospective analysis of 113 patients treated with antiEGFR monoclonal antibodies found the V600E BRAF mutation in $14 \%$ of the KRAS WT patients and was associated with no response to therapy and a statistically significant shorter progression-free survival and overall survival compared with BRAF WT patients [59]. In De Roock's retrospective analysis of tumor samples from patients treated with cetuximab plus chemotherapy, a BRAF mutation was discovered in $4.7 \%$ of tumors [26]. In KRAS wild types, carriers of BRAF mutations had a significantly lower response rate to cetuximab than in BRAF wild types $(8.3 \%$ versus $38.0 \%, P=.0012)$, a significantly shorter PFS ( 8 versus 26 weeks, $P<.0001$ ), and a significantly shorter OS (26 versus 54 weeks, $P<$ .0001) [26]. KRAS and BRAF mutation status do not, however, appear to affect the clinical benefit of oxaliplatin or irinotecan on PFS or OS [62]. Several compounds (PLX4032, PLX4720, and GDC-0879) which selectively inhibit the kinase enzyme BRAF containing the V600E mutation are in clinical development [63]. In BRAF mutant cancer cell lines, these selective BRAF inhibitors potently block RAF-MEKERK signaling. However, in those tumors that are BRAF WT, but possess a KRAS mutation, these BRAF inhibitors activate this same pathway and therefore should be avoided in those cancers with RAS mutations [64-66]. 
TABLE 2: Clinical trials with retrospective subset analyses of antiEGFR efficacy in relation to KRAS mutation status.

\begin{tabular}{|c|c|c|c|c|c|c|c|}
\hline Study & Setting & Treatment & KRAS genotype & No. of patients & ORR (\%) & mPFS (mos) & $\operatorname{mOS}(\mathrm{mos})$ \\
\hline \multicolumn{8}{|c|}{ Single arm studies } \\
\hline Lièvre et al. [34] & $\begin{array}{l}\text { Second-line } \\
\text { treatment }\end{array}$ & Cetuximab & $\begin{array}{l}\text { WT } \\
\text { Mut }\end{array}$ & $\begin{array}{l}65 \\
24\end{array}$ & $\begin{array}{c}40^{*} \\
0\end{array}$ & $\begin{array}{c}31.4 \mathrm{wk}^{*} \\
10.1\end{array}$ & $\begin{array}{c}14.3^{*} \\
10.1\end{array}$ \\
\hline De Roock et al. [29] & $\begin{array}{l}\text { Irinotecan } \\
\text { refractory }\end{array}$ & $\begin{array}{l}\text { Cetuximab or } \\
\text { cetuximab }+ \\
\text { irinotecan }\end{array}$ & $\begin{array}{l}\text { WT } \\
\text { Mut }\end{array}$ & $\begin{array}{l}57 \\
46\end{array}$ & $\begin{array}{c}41^{\dagger} \\
0\end{array}$ & $\begin{array}{c}34 \mathrm{wk}^{\dagger} \text { (combo) } \\
12 \text { (cetux) } \\
12\end{array}$ & $\begin{array}{c}44.7 \mathrm{wk}^{\dagger} \text { (combo) } \\
27 \mathrm{wk} \text { (cetux) } \\
25.3-27.3\end{array}$ \\
\hline $\begin{array}{l}\text { Khambata-Ford } \\
\text { et al. [28] }\end{array}$ & $\begin{array}{l}\text { Second or } \\
\text { third-line } \\
\text { treatment }\end{array}$ & Cetuximab & $\begin{array}{l}\text { WT } \\
\text { Mut }\end{array}$ & $\begin{array}{l}50 \\
30\end{array}$ & $\begin{array}{c}10 \\
0\end{array}$ & N.R. & N.R. \\
\hline Di Fiore et al. [47] & $\begin{array}{l}\text { Refractory } \\
\text { disease }\end{array}$ & $\begin{array}{l}\text { Cetuximab + } \\
\text { chemotherapy }\end{array}$ & $\begin{array}{l}\text { WT } \\
\text { Mut }\end{array}$ & $\begin{array}{l}43 \\
16\end{array}$ & $\begin{array}{c}20.3 \\
0\end{array}$ & N.R. & N.R. \\
\hline Benvenuti et al. [48] & $\begin{array}{l}\text { Various lines } \\
\text { of treatment }\end{array}$ & $\begin{array}{l}\text { Cetuximab or } \\
\text { panitumumab } \\
\text { or cetuximab }+ \\
\text { chemotherapy }\end{array}$ & $\begin{array}{l}\text { WT } \\
\text { Mut }\end{array}$ & $\begin{array}{l}32 \\
16\end{array}$ & $\begin{array}{c}31 \\
6\end{array}$ & N.R. & N.R. \\
\hline \multicolumn{8}{|c|}{ Randomized studies } \\
\hline Amado et al. [24] & $\begin{array}{l}\text { Refractory } \\
\text { disease }\end{array}$ & $\begin{array}{l}\text { Panitumumab + } \\
\text { BSC vs. BSC }\end{array}$ & $\begin{array}{c}\text { WT } \\
\text { Mut vs. } \\
\text { WT } \\
\text { Mut }\end{array}$ & $\begin{array}{c}124 \\
84 \\
119 \\
100\end{array}$ & $\begin{array}{c}17 \\
0 \\
0 \\
0\end{array}$ & $\begin{array}{c}12.3 \mathrm{wk}^{*} \\
7.4 \mathrm{wk} \\
7.3 \mathrm{wk} \\
7.3 \mathrm{wk}\end{array}$ & $\begin{array}{l}8.1 \\
4.9 \\
7.6 \\
4.4 \\
\end{array}$ \\
\hline Van Cutsem et al. [33] & $\begin{array}{l}\text { First-line } \\
\text { treatment }\end{array}$ & $\begin{array}{l}\text { FOLFIRI + } \\
\text { cetuximab vs. } \\
\text { FOLFIRI }\end{array}$ & $\begin{array}{c}\text { WT } \\
\text { Mut vs. } \\
\text { WT } \\
\text { Mut }\end{array}$ & $\begin{array}{c}172 \\
105 \\
176 \\
87\end{array}$ & $\begin{array}{l}59.3 \\
36.2 \\
43.2 \\
40.2\end{array}$ & $\begin{array}{c}9.9^{*} \\
7.6 \\
8.7 \\
8.1\end{array}$ & $\begin{array}{l}24.9 \\
17.5 \\
21.0 \\
17.7\end{array}$ \\
\hline Van Cutsem et al. [42] & $\begin{array}{l}\text { First-line } \\
\text { treatment }\end{array}$ & $\begin{array}{l}\text { FOLFIRI + } \\
\text { cetuximab vs. } \\
\text { FOLFIRI }\end{array}$ & $\begin{array}{c}\text { WT } \\
\text { Mut vs. } \\
\text { WT } \\
\text { Mut }\end{array}$ & $\begin{array}{l}316 \\
214 \\
350 \\
183\end{array}$ & $\begin{array}{c}57.3^{*} \\
31.3 \\
39.7 \\
36.1\end{array}$ & $\begin{array}{c}9.9^{*} \\
7.4 \\
8.4 \\
7.7\end{array}$ & $\begin{array}{c}23.5^{*} \\
16.2 \\
20.0 \\
16.7\end{array}$ \\
\hline Bokemeyer et al. [31] & $\begin{array}{l}\text { First-line } \\
\text { treatment }\end{array}$ & $\begin{array}{l}\text { FOLFOX + } \\
\text { cetuximab vs. } \\
\text { FOLFOX }\end{array}$ & $\begin{array}{c}\text { WT } \\
\text { Mut vs. } \\
\text { WT } \\
\text { Mut }\end{array}$ & $\begin{array}{l}61 \\
52 \\
73 \\
47\end{array}$ & $\begin{array}{c}61^{*} \\
33 \\
37 \\
49\end{array}$ & $\begin{array}{c}7.7^{*} \\
5.5 \\
7.2 \\
8.6\end{array}$ & N.R. \\
\hline Bokemeyer et al. [43] & $\begin{array}{l}\text { First-line } \\
\text { treatment }\end{array}$ & $\begin{array}{l}\text { FOLFOX + } \\
\text { cetuximab vs. } \\
\text { FOLFOX }\end{array}$ & $\begin{array}{c}\text { WT } \\
\text { Mut vs. } \\
\text { WT } \\
\text { Mut }\end{array}$ & $\begin{array}{l}82 \\
77 \\
97 \\
59\end{array}$ & $\begin{array}{c}57^{*} \\
34 \\
34 \\
53\end{array}$ & $\begin{array}{c}8.3^{*} \\
5.5 \\
7.2 \\
8.6\end{array}$ & $\begin{array}{l}22.8 \\
18.5 \\
13.4 \\
17.5\end{array}$ \\
\hline Karapetis et al. [35] & $\begin{array}{l}\text { Refractory } \\
\text { disease }\end{array}$ & $\begin{array}{l}\text { Cetuximab + } \\
\text { BSC vs. BSC }\end{array}$ & $\begin{array}{c}\text { WT } \\
\text { Mut vs. } \\
\text { WT } \\
\text { Mut }\end{array}$ & $\begin{array}{c}115 \\
81 \\
113 \\
83\end{array}$ & $\begin{array}{c}12.8 \\
1.2 \\
0 \\
0\end{array}$ & $\begin{array}{c}3.7^{*} \\
1.8 \\
1.9 \\
1.8\end{array}$ & $\begin{array}{c}9.5^{*} \\
4.5 \\
4.8 \\
4.6\end{array}$ \\
\hline Siena et al. [44] & $\begin{array}{l}\text { First-line } \\
\text { treatment }\end{array}$ & $\begin{array}{l}\text { FOLFOX + } \\
\text { panitumumab } \\
\text { vs. FOLFOX }\end{array}$ & $\begin{array}{l}\mathrm{WT}=656 \\
\mathrm{Mut}=440\end{array}$ & & $\begin{array}{l}55 \\
48\end{array}$ & $\begin{array}{c}9.6(\mathrm{wt})^{*} \\
7.3(\mathrm{mut}) \\
8.0(\mathrm{wt}) \\
8.8 \text { (mut) }\end{array}$ & N.R. \\
\hline Kohne et al. [45] & $\begin{array}{l}\text { First-line } \\
\text { treatment }\end{array}$ & $\begin{array}{l}\text { FOLFIRI + } \\
\text { panitumumab }\end{array}$ & $\begin{array}{l}\text { WT } \\
\text { Mut }\end{array}$ & $\begin{array}{l}85 \\
57\end{array}$ & $\begin{array}{l}48 \\
29\end{array}$ & N.R. & N.R. \\
\hline
\end{tabular}


Table 2: Continued.

\begin{tabular}{|c|c|c|c|c|c|c|c|}
\hline Study & Setting & Treatment & KRAS genotype & No. of patients & ORR $(\%)$ & mPFS (mos) & $\mathrm{mOS}(\mathrm{mos})$ \\
\hline Tol et al. [49] & $\begin{array}{l}\text { First-line } \\
\text { treatment }\end{array}$ & $\begin{array}{l}\text { CAPOX + } \\
\text { bevacizumab + } \\
\text { cetuximab vs. } \\
\text { CAPOX + } \\
\text { bevacizumab }\end{array}$ & $\begin{array}{l}\text { WT } \\
\text { Mut } \\
\text { WT } \\
\text { Mut }\end{array}$ & $\begin{array}{c}158 \\
98 \\
156 \\
108\end{array}$ & $\begin{array}{c}50.0 \\
59.2 \\
61.4^{*} \\
45.9\end{array}$ & $\begin{array}{c}10.5^{*} \\
8.1 \\
10.6 \\
12.5\end{array}$ & $\begin{array}{l}21.8 \\
17.2 \\
22.4 \\
24.9\end{array}$ \\
\hline Hecht et al. [50] & $\begin{array}{l}\text { First-line } \\
\text { treatment }\end{array}$ & $\begin{array}{l}\text { FOLFOX + } \\
\text { bevacizumab + } \\
\text { panitumumab } \\
\text { vs. FOLFOX + } \\
\text { bevacizumab }\end{array}$ & $\begin{array}{l}\text { WT } \\
\text { Mut } \\
\text { WT } \\
\text { Mut }\end{array}$ & $\begin{array}{l}201 \\
135 \\
203 \\
125\end{array}$ & $\begin{array}{l}50 \\
47 \\
56 \\
44\end{array}$ & $\begin{array}{c}9.8 \\
10.4 \\
11.5 \\
11.0\end{array}$ & $\begin{array}{l}20.7 \\
19.3 \\
24.5 \\
19.3\end{array}$ \\
\hline
\end{tabular}

* Statistically significant improvement

tStatistically significant improvement for the combination of cetuximab and irinotecan only.

ORR: overall response rate; mPFS: median progression-free survival; mOS: median overall survival; N.R.: not reported; BSC: best supportive care.

The mitogen-activated protein kinase kinase (MEK, also known as MAP2K) is downstream of BRAF in the RAS-RAFMEK signaling cascade of the EGFR and uses extracellular signal-regulated kinase (ERK) as a substrate (see Figure 1) [67]. A number of MEK inhibitors such as AS703026, AZD6244 and RO5068760 have been or currently are being investigated in phase 1 and 2 clinical trials $[68,69]$. The development of several MEK inhibitors has been halted because of either very low response rates or due to ocular toxicity [70]. These agents have however shown substantial preclinical activity in tumor cell lines harboring the BRAF V600E gene mutation [71]. It has been established that KRAS has a number of downstream effectors that are not blocked by MEK inhibition, and indeed BRAF mutant cell lines were found to be more sensitive to MEK inhibitors than KRAS mutant cells [71]. It is imperative to be able to identify which patients are likely to respond to MEK inhibitors, and it appears that those with BRAF mutations are a good start. Given that KRAS signaling operates through a number of downstream effectors, those with KRAS mutations may require a combination of targeted agents. Preclinical evidence suggests that BRAF gene amplification is a mechanism of resistance to both MEK and BRAF inhibitors and a combination of these inhibitors may be a strategy to overcome this [72].

An additional EGFR pathway is the PTEN/PI3K/AKT pathway [phosphatase and tensin homologue gene (PTEN)]. PTEN encodes a phosphatase which uses phosphatidylinositol-3,4,5-triphosphate (PIP-3) as a major substrate [73]. Loss of PTEN function leads to increased PIP3 concentration, with resultant AKT hyperphosphorylation protecting tumor cells from apoptosis [73]. Roughly 60\% of primary CRCs have a hyperphosphorylated AKT [74]. PTEN loss, activating mutations of phosphatidylinositol 3kinase catalytic alpha polypeptide (PIK3CA) and activating mutations in KRAS/BRAF/MAPK confer resistance to apoptosis induced by cetuximab [75]. In patients with KRAS WT tumors treated with a cetuximab-based regimen, PTEN loss was associated with a significantly shorter OS [60]. Approximately one third of CRCs harbor activating somatic mutations in PIK3CA, and it has been reported that these mutations are predictive of lack of benefit from antiEGFR therapy [76]. Additional genetic alterations which could confer resistance to antiEGFR monoclonal antibodies include an inhibitor of PI3K signaling; coamplification of PAK4 (p-21-activated protein kinase) and AKT, which are downstream mediators of PI3K signaling; and amplification of IRS2 (insulin receptor substrate 2), which is an upstream activator of PI3K signaling $[77,78]$.

\section{Strategies to Overcome Resistance}

A number of approaches to the problem of resistance to antiEGFR monoclonal antibody therapy have been studied and are ongoing. Combining antiEGFR monoclonal antibodies with cytotoxic chemotherapy has already been discussed. Erlotinib and gefitinib, two oral small molecule EGFR inhibitors, are inactive by themselves [79, 80]. The combination of erlotinib with capecitabine and oxaliplatin in previously treated patients and the combination of gefitinib with FOLFOX were investigated in small phase II studies with favorable results, however randomized trials with chemotherapy alone as a control are needed [81-83]. Dual antiEGFR therapy with antiEGFR monoclonal antibodies plus antiEGFR TK inhibitors may overcome resistance to either drug alone. A 41\% response rate was reported for the combination of cetuximab and erlotinib in patients with refractory disease, however this was limited to patients with KRAS and BRAF WT tumors [84].

EGFR and vascular endothelial growth factor (VEGF) have several signal transduction pathways in common, with preclinical data revealing that antiEGFR and antiVEGF drug combinations have synergistic activity [85]. The BOND-2 study randomized patients with irinotecan- and oxaliplatinrefractory but bevacizumab naïve disease to cetuximab and bevacizumab with or without irinotecan [21]. Response rates, TTP and OS favored the triple drug regimen, however, these results did not hold up in a subsequent study of this combination [21, 22]. Two subsequent randomized phase III trials have shown that combinations of antiEGFR 
monoclonal antibodies plus bevacizumab do not improve outcomes and can actually cause increased toxicity irrespective of KRAS mutational status. The PACCE trial evaluated panitumumab combined with oxaliplatin- or irinotecanbased chemotherapy plus bevacizumab. The dual monoclonal antibody arm was associated with increased toxicity and significantly shorter PFS in patients with both KRAS WT and mutant tumors [50]. Similar results were observed with the combination of cetuximab to a regimen containing capecitabine, oxaliplatin, and bevacizumab in the CAIRO2 trial [49].

Novel agents and combinations are being employed in an attempt to overcome antiEGFR monoclonal antibody resistance. Motesanib, an oral inhibitor of VEGF, platelet derived growth factor (PDFG) and Kit receptors is being investigated with or without panitumumab in patients with refractory disease [86]. A number of inhibitors of the mutant BRAF kinase are in clinical development, as discussed above [87]. AMG 102 is an investigational monoclonal antibody against human hepatocyte growth factor (also known as cMET, of which overexpression correlates with cetuximab resistance) is being studied in combination with panitumumab in patients with metastatic CRC $[88,89]$.

\section{Neoadjuvant and Adjuvant Therapy}

Given the clinical benefit of antiEGFR monoclonal antibodies in patients with metastatic disease, evaluation of these therapies as postoperative (adjuvant) treatment was warranted. In the adjuvant setting, eradication of micrometastatic disease is associated with increased cure rates. N0147 randomized 1760 patients with resected stage III KRAS WT colon cancer to FOLFOX with or without cetuximab [90]. Interim analysis led to premature closure of this trial after it was determined that no group of patients benefited from cetuximab [90]. Initially this trial enrolled patients regardless of KRAS mutational status, and among 658 patients with mutant KRAS, the addition of cetuximab to FOLFOX resulted in impaired disease-free survival (DFS) and a trend toward impaired OS [91].

In patients with rectal cancer, EGFR is a logical target in combination with neoadjuvant radiotherapy (RT). Retrospective analyses have demonstrated lower pathologic complete response (pCR) rates and shorter DFS in patients with rectal cancer expressing EGFR who were treated with neoadjuvant RT, suggesting that radiosensitivity might be increased by targeting the EGFR $[92,93]$. Several phase I/II studies have investigated the combinations of cetuximab and chemoradiotherapy in the neoadjuvant setting for patients with rectal cancer. These studies have demonstrated that cetuximab could be safely combined with preoperative chemoradiotherapy but the pCR rates have been low (5$12 \%)$ [94-100]. In two of these studies [96, 99], subsequent analyses were done to correlate KRAS mutation status with response rate. Among patients with KRAS WT tumors, Bengala et al. reported a trend toward a greater rate of tumor regression $36.7 \%$ for KRAS WT versus $11 \%$ for KRAS mutant), however it did not reach statistical significance $(P=.12)$ [101]. Debucquoy et al. also did not find a correlation between KRAS WT tumors and pathologic response to therapy [102]. To our knowledge, panitumumab has not been studied in combination with RT in patients with rectal cancer. Given the failure of antiEGFR monoclonal antibodies to demonstrate a benefit in the adjuvant setting for stage III WT KRAS colon cancer, the value of further study of these agents for rectal cancer is doubtful.

Preclinically gefitinib has demonstrated improved radiosensitization [103]. Valentini et al. investigated the combination of gefitinib, continuous infusion 5-fluorouracil (5-FU) and pelvic RT in 41 patients with locally advanced rectal cancer and reported a pCR rate of $30 \%$, however toxicity was an issue and further studies are necessary to establish the safety of this combination [104].

The effect of combined antiEGFR and antiVEGF therapy in combination with preoperative chemoradiotherapy for rectal cancer remains unknown, however given the negative results reported for combined EGFR and VEGF blockade in patients with metastatic CRC in combination with chemotherapy, studies investigating this avenue are unlikely $[22,49,50]$. Blaszkowsky et al. performed a small study investigating the combination of bevacizumab, erlotinib and 5-FU with RT in patients with locally advanced rectal cancer [105]. The regimen was found to be well-tolerated and highly active with a pCR rate of $47 \%$ and may deserve further investigation. However, the value of $\mathrm{pCR}$ as a surrogate for DFS and OS is uncertain.

\section{Conclusion}

Anti-EGFR monoclonal antibodies are among the standard treatment options for patients with metastatic CRC given their established efficacy. It is now clear that the benefit of antiEGFR monoclonal antibodies is isolated to patients with KRAS WT tumors. It appears that KRAS mutational status is just the beginning of our understanding of the EGFR as an integral component of the biology of CRC. Given that only a subset of patients respond to antiEGFR therapy, there is a need for better predictors to guide patient selection for such therapy. Several important components of the EGFR signaling pathway have been discovered, including BRAF, PTEN, AKT and PI3K, which deserve further study as predictors of response to existing treatments, or as targets of new interventions. The unexpected detrimental outcome associated with combined EGFR and VEGF blockade is a reminder of how much there is still to learn. New combinations and novel agents will continue to shed light on how to overcome resistance to inhibitors of the EGFR pathway, and hopefully new targets will be identified. Further study of how to employ our knowledge of EGFR pathway inhibitors to improve outcomes in the adjuvant and neoadjuvant setting is also warranted.

\section{References}

[1] C. H. Heldin, "Dimerization of cell surface receptors in signal transduction,” Cell, vol. 80, no. 2, pp. 213-223, 1995.

[2] G. Carpenter, "Receptors for epidermal growth factor and other polypeptide mitogens," Annual Review of Biochemistry, vol. 56, pp. 881-914, 1987. 
[3] G. Carpenter and S. Cohen, "Epidermal growth factor," The Journal of Biological Chemistry, vol. 265, no. 14, pp. 77097712, 1990.

[4] F. Loupakis, L. Pollina, I. Stasi et al., "PTEN expression and KRAS mutations on primary tumors and metastases in the prediction of benefit from cetuximab plus irinotecan for patients with metastatic colorectal cancer," Journal of Clinical Oncology, vol. 27, no. 16, pp. 2622-2629, 2009.

[5] A. Citri and Y. Yarden, "EGF-ERBB signalling: towards the systems level," Nature Reviews Molecular Cell Biology, vol. 7, no. 7, pp. 505-516, 2006.

[6] N. E. Hynes and H. A. Lane, "ERBB receptors and cancer: the complexity of targeted inhibitors," Nature Reviews Cancer, vol. 5, no. 5, pp. 341-354, 2005.

[7] J. Downward, Y. Yarden, E. Mayes et al., "Close similarity of epidermal growth factor receptor and v-erb-B oncogene protein sequences," Nature, vol. 307, no. 5951, pp. 521-527, 1984.

[8] F. X. Real, W. J. Rettig, and P. G. Chesa, "Expression of epidermal growth factor receptor in human cultured cells and tissues: relationship to cell lineage and stage of differentiation," Cancer Research, vol. 46, no. 9, pp. 47264731, 1986.

[9] NCCN Clinical Practice Guidelines in Oncology. Colon Cancer, vol. 3, NCCN, Gaithersburg, Md, USA, 2010.

[10] C. M. Croce, "Oncogenes and cancer," The New England Journal of Medicine, vol. 358, no. 5, pp. 502-511, 2008.

[11] N. Normanno, C. Bianco, A. De Luca, M. R. Maiello, and D. S. Salomon, "Target-based agents against ErbB receptors and their ligands: a novel approach to cancer treatment," Endocrine-Related Cancer, vol. 10, no. 1, pp. 1-21, 2003.

[12] L. B. Saltz, N. J. Meropol, P. J. Loehrer, M. N. Needle, J. Kopit, and R. J. Mayer, "Phase II trial of cetuximab in patients with refractory colorectal cancer that expresses the epidermal growth factor receptor," Journal of Clinical Oncology, vol. 22, no. 7, pp. 1201-1208, 2004.

[13] D. Cunningham, Y. Humblet, S. Siena et al., "Cetuximab monotherapy and cetuximab plus irinotecan in irinotecanrefractory metastatic colorectal cancer," The New England Journal of Medicine, vol. 351, no. 4, pp. 337-345, 2004.

[14] H. J. Lenz, E. Van Cutsem, S. Khambata-Ford et al., "Multicenter phase II and translational study of cetuximab in metastatic colorectal carcinoma refractory to irinotecan, oxaliplatin, and fluoropyrimidines," Journal of Clinical Oncology, vol. 24, no. 30, pp. 4914-4921, 2006.

[15] G. Folprecht, M. P. Lutz, P. Schöffski et al., "Cetuximab and irinotecan/5-fluorouracil/folinic acid is a safe combination for the first-line treatment of patients with epidermal growth factor receptor expressing metastatic colorectal carcinoma," Annals of Oncology, vol. 17, no. 3, pp. 450-456, 2006.

[16] D. J. Jonker, C. J. O'Callaghan, C. S. Karapetis et al., "Cetuximab for the treatment of colorectal cancer," The New England Journal of Medicine, vol. 357, no. 20, pp. 2040-2048, 2007.

[17] J. Tabernero, E. Van Cutsem, E. Díaz-Rubio et al., "Phase II trial of cetuximab in combination with fluorouracil, leucovorin, and oxaliplatin in the first-line treatment of metastatic colorectal cancer," Journal of Clinical Oncology, vol. 25, no. 33, pp. 5225-5232, 2007.

[18] A. F. Sobrero, J. Maurel, L. Fehrenbacher et al., "EPIC: phase III trial of cetuximab plus irinotecan after fluoropyrimidine and oxaliplatin failure in patients with metastatic colorectal cancer," Journal of Clinical Oncology, vol. 26, no. 14, pp. 23112319, 2008.
[19] E. Van Cutsem, M. Nowacki, I. Lang et al., "Randomized phase III study of irinotecan and 5-FU/FA with or without cetuximab in the first-line treatment of patients with metastatic colorectal cancer (mCRC): the CRYSTAL trial," Journal of Clinical Oncology, vol. 25, no. 18, supplement, p. 164s, 2007.

[20] E. Van Cutsem, M. Peeters, S. Siena et al., "Open-label phase III trial of panitumumab plus best supportive care compared with best supportive care alone in patients with chemotherapy-refractory metastatic colorectal cancer," Journal of Clinical Oncology, vol. 25, no. 13, pp. 1658-1664, 2007.

[21] L. B. Saltz, H. J. Lenz, H. L. Kindler et al., "Randomized phase II trial of cetuximab, bevacizumab, and irinotecan compared with cetuximab and bevacizumab alone in irinotecanrefractory colorectal cancer: the BOND-2 study," Journal of Clinical Oncology, vol. 25, no. 29, pp. 4557-4561, 2007.

[22] N. H. Segal, D. Reidy-Lagunes, M. Capanu et al., "Phase II study of bevacizumab in combination with cetuximab plus irinotecan in irinotecan-refractory colorectal cancer (CRC) patients who have progressed on a bevacizumabcontaining regimen (The BOND 2.5 Study)," Journal of Clinical Oncology, vol. 27, no. 15, supplement, 2009, ASCO Annual Meeting, abstract no. 4087.

[23] M. Malumbres and M. Barbacid, "RAS oncogenes: the first 30 years," Nature Reviews Cancer, vol. 3, no. 6, pp. 459-465, 2003.

[24] R. G. Amado, M. Wolf, M. Peeters et al., "Wild-type KRAS is required for panitumumab efficacy in patients with metastatic colorectal cancer," Journal of Clinical Oncology, vol. 26, no. 10, pp. 1626-1634, 2008.

[25] C. J. Allegra, J. M. Jessup, M. R. Somerfield et al., "American society of clinical oncology provisional clinical opinion: testing for KRAS gene mutations in patients with metastatic colorectal carcinoma to predict response to anti-epidermal growth factor receptor monoclonal antibody therapy," Journal of Clinical Oncology, vol. 27, no. 12, pp. 2091-2096, 2009.

[26] W. De Roock, B. Claes, D. Bernasconi et al., "Effects of KRAS, BRAF, NRAS, and PIK3CA mutations on the efficacy of cetuximab plus chemotherapy in chemotherapy-refractory metastatic colorectal cancer: a retrospective consortium analysis," The Lancet Oncology, vol. 11, no. 8, pp. 753-762, 2010.

[27] J. Baselga and N. Rosen, "Determinants of RASistance to anti-epidermal growth factor receptor agents," Journal of Clinical Oncology, vol. 26, no. 10, pp. 1582-1584, 2008.

[28] S. Khambata-Ford, C. R. Garrett, N. J. Meropol et al., "Expression of epiregulin and amphiregulin and K-ras mutation status predict disease control in metastatic colorectal cancer patients treated with cetuximab," Journal of Clinical Oncology, vol. 25, no. 22, pp. 3230-3237, 2007.

[29] W. De Roock, H. Piessevaux, J. De Schutter et al., "KRAS wild-type state predicts survival and is associated to early radiological response in metastatic colorectal cancer treated with cetuximab," Annals of Oncology, vol. 19, no. 3, pp. 508515, 2008.

[30] C. J. Punt, J. Tol, C. J. Rodenburg et al., "Randomized phase III study of capecitabine, oxaliplatin, and bevacizumab with or without cetuximab in advanced colorectal cancer, the CAIRO2 study of the Dutch Colorectal Cancer Group," Journal of Clinical Oncology, vol. 26, supplement, 2008, abstract LBA 4011.

[31] C. Bokemeyer, I. Bondarenko, A. Makhson et al., "Fluorouracil, leucovorin, and oxaliplatin with and without cetuximab in the first-line treatment of metastatic colorectal 
cancer," Journal of Clinical Oncology, vol. 27, no. 5, pp. 663671, 2009.

[32] S. Tejpar, M. Peeters, Y. Humblet et al., "Relationship of efficacy with KRAS status (wild type versus mutant) in patients with irinotecan-refractory metastatic colorectal cancer, treated with irinotecan and escalating doses of cetuximab: the EVEREST experience (preliminary data)," Journal of Clinical Oncology, vol. 26, supplement, 2008, abstract no. 4001 .

[33] E. Van Cutsem, C. H. Köhne, E. Hitre et al., "Cetuximab and chemotherapy as initial treatment for metastatic colorectal cancer," The New England Journal of Medicine, vol. 360, no. 14, pp. 1408-1417, 2009.

[34] A. Lièvre, J. B. Bachet, V. Boige et al., "KRAS mutations as an independent prognostic factor in patients with advanced colorectal cancer treated with cetuximab," Journal of Clinical Oncology, vol. 26, no. 3, pp. 374-379, 2008.

[35] C. S. Karapetis, S. Khambata-Ford, D. J. Jonker et al., "Kras mutations and benefit from cetuximab in advanced colorectal cancer," The New England Journal of Medicine, vol. 359, no. 17, pp. 1757-1765, 2008.

[36] D. Santini, F. Loupakis, B. Vincenzi et al., "High concordance of KRAS status between primary colorectal tumors and related metastatic sites: implications for clinical practice," Oncologist, vol. 13, no. 12, pp. 1270-1275, 2008.

[37] S. Artale, A. Sartore-Bianchi, S. M. Veronese et al., "Mutations of KRAS and BRAF in primary and matched metastatic sites of colorectal cancer," Journal of Clinical Oncology, vol. 26, no. 25, pp. 4217-4219, 2008.

[38] M. C. Etienne-Grimaldi, J. L. Formento, M. Francoual et al., "K-Ras mutations and treatment outcome in colorectal cancer patients receiving exclusive fluoropyrimidine therapy," Clinical Cancer Research, vol. 14, no. 15, pp. 4830-4835, 2008.

[39] G. Folprecht, T. Gruenberger, W. O. Bechstein et al., "Tumour response and secondary resectability of colorectal liver metastases following neoadjuvant chemotherapy with cetuximab: the CELIM randomised phase 2 trial," The Lancet Oncology, vol. 11, no. 1, pp. 38-47, 2010.

[40] S. E. Baldus, K. L. Schaefer, R. Engers, D. Hartleb, N. H. Stoecklein, and H. E. Gabbert, "Prevalence and heterogeneity of KRAS, BRAF, and PIK3CA mutations in primary colorectal adenocarcinomas and their corresponding metastases," Clinical Cancer Research, vol. 16, no. 3, pp. 790-799, 2010.

[41] A. Mancuso, R. Sollami, F. Recine et al., "Patient with colorectal cancer with heterogeneous KRAS molecular status responding to cetuximab-based chemotherapy," Journal of Clinical Oncology, vol. 28, no. 36, pp. e756-e758, 2010.

[42] E. Van Cutsem, I. Lang, G. Folprecht et al., "Cetuximab plus FOLFIRI in the treatment of metastatic colorectal cancer: the influence of KRAS and BRAF biomarkers on outcome: updated data from the CRYSTAL trial," in Proceedings of the Gastrointestinal Cancers Symposium, Orlando, Fla, USA, January 2010, abstract no. 281.

[43] C. Bokemeyer, I. Bondarenko, J. T. Hartmann et al., "Biomarkers predictive for outcome in patients with metastatic colorectal cancer treated with first-line FOLFOX4 plus or minus cetuximab: updated data from the OPUS study," in Proceedings of the ASCO Gastrointestinal Cancers Symposium, Orlando, Fla, USA, January 2010, abstract no. 428.

[44] S. Siena, J. Cassidy, J. Tabernero et al., "Randomized phase III study of panitumumab with FOLFOX4 compared to FOLFOX4 alone as first-line treatment for metastatic colorectal cancer: PRIME trial," in Proceedings of the Gastrointestinal
Cancers Symposium, Orlando, Fla, USA, January 2010, abstract no. 283.

[45] C. Kohne, K. Mineur, R. Greil et al., "Primary analysis of a phase II study (20060314) combining first-line panitumumab with FOLFIRI in the treatment of patients with metastatic colorectal cancer," in Proceedings of the Gastrointestinal Cancers Symposium, Orlando, Fla, USA, January 2010, abstract no. 414 .

[46] J. Hecht, E. Mitchell, J. Baranda et al., "Panitumumab antitumor activity in patients (pts) with metastatic colorectal cancer (mCRC) expressing low (1-9\%) or negative $(<1 \%)$ levels of epidermal growth receptor (EGFr)," Journal of Clinical Oncology, vol. 24, supplement, 2006, abstract no. 3506.

[47] F. Di Fiore, F. Blanchard, F. Charbonnier et al., "Clinical relevance of KRAS mutation detection in metastatic colorectal cancer treated by Cetuximab plus chemotherapy," British Journal of Cancer, vol. 96, no. 8, pp. 1166-1169, 2007.

[48] S. Benvenuti, A. Sartore-Bianchi, F. Di Nicolantonio et al., "Oncogenic activation of the RAS/RAF signaling pathway impairs the response of metastatic colorectal cancers to antiepidermal growth factor receptor antibody therapies," Cancer Research, vol. 67, no. 6, pp. 2643-2648, 2007.

[49] J. Tol, M. Koopman, A. Cats et al., "Chemotherapy, bevacizumab, and cetuximab in metastatic colorectal cancer," The New England Journal of Medicine, vol. 360, pp. 563-572, 2009.

[50] J. R. Hecht, E. Mitchell, T. Chidiac et al., "A randomized phase IIIB trial of chemotherapy, bevacizumab, and panitumumab compared with chemotherapy and bevacizumab alone for metastatic colorectal cancer," Journal of Clinical Oncology, vol. 27, no. 5, pp. 672-680, 2009.

[51] H. Linardou, I. J. Dahabreh, D. Kanaloupiti et al., "Assessment of somatick-RAS mutations as a mechanism associated with resistance to EGFR-targeted agents: a systematic review and meta-analysis of studies in advanced non-small-cell lung cancer and metastatic colorectal cancer," The Lancet Oncology, vol. 9, no. 10, pp. 962-972, 2008.

[52] J. L. Bos, E. R. Fearon, S. R. Hamilton et al., "Prevalence of ras gene mutations in human colorectal cancers," Nature, vol. 327, no. 6120, pp. 293-297, 1987.

[53] B. Vogelstein, E. R. Fearon, S. R. Hamilton et al., "Genetic alterations during colorectal-tumor development," The New England Journal of Medicine, vol. 319, no. 9, pp. 525-532, 1988.

[54] D. Lambrechts, W. De Roock, H. Prenen et al., "The role of KRAS, BRAF, NRAS, and PIK3CA mutations as markers of resistance to cetuximab in chemorefractory metastatic colorectal cancer," Journal of Clinical Oncology, vol. 27, no. 15, supplement, 2009, abstract no. 4020.

[55] N. Irahara, Y. Baba, K. Nosho et al., "NRAS mutations are rare in colorectal cancer," Diagnostic Molecular Pathology, vol. 19, no. 3, pp. 157-163, 2010.

[56] H. Davies, G. R. Bignell, C. Cox et al., "Mutations of the BRAF gene in human cancer," Nature, vol. 417, no. 6892, pp. 949-954, 2002.

[57] J. Tol, I. D. Nagtegaal, and C. J. A. Punt, "BRAF mutation in metastatic colorectal cancer," The New England Journal of Medicine, vol. 361, no. 1, pp. 98-99, 2009.

[58] S. Siena, A. Sartore-Bianchi, F. Di Nicolantonio, J. Balfour, and A. Bardelli, "Biomarkers predicting clinical outcome of epidermal growth factor receptor-targeted therapy in metastatic colorectal cancer," Journal of the National Cancer Institute, vol. 101, no. 19, pp. 1308-1324, 2009. 
[59] F. Di Nicolantonio, M. Martini, F. Molinari et al., "Wild-type BRAF is required for response to panitumumab or cetuximab in metastatic colorectal cancer," Journal of Clinical Oncology, vol. 26, no. 35, pp. 5705-5712, 2008.

[60] P. Laurent-Puig, A. Cayre, G. Manceau et al., "Analysis of PTEN, BRAF, and EGFR status in determining benefit from cetuximab therapy in wild-type KRAS metastatic colon cancer," Journal of Clinical Oncology, vol. 27, no. 35, pp. 59245930, 2009.

[61] F. Loupakis, A. Ruzzo, C. Cremolini et al., "KRAS codon 61, 146 and BRAF mutations predict resistance to cetuximab plus irinotecan in KRAS codon 12 and 13 wild-type metastatic colorectal cancer," British Journal of Cancer, vol. 101, no. 4, pp. 715-721, 2009.

[62] S. D. Richman, M. T. Seymour, P. Chambers et al., "KRAS and BRAF mutations in advanced colorectal cancer are associated with poor prognosis but do not preclude benefit from oxaliplatin or irinotecan: results from the MRC FOCUS trial," Journal of Clinical Oncology, vol. 27, no. 35, pp. 59315937, 2009.

[63] K. Cichowski and P. A. Jänne, "Drug discovery: inhibitors that activate," Nature, vol. 464, no. 7287, pp. 358-359, 2010.

[64] P. I. Poulikakos, C. Zhang, G. Bollag, K. M. Shokat, and N. Rosen, "RAF inhibitors transactivate RAF dimers and ERK signalling in cells with wild-type BRAF," Nature, vol. 464, no. 7287, pp. 427-430, 2010.

[65] G. Hatzivassiliou, K. Song, I. Yen et al., "RAF inhibitors prime wild-type RAF to activate the MAPK pathway and enhance growth," Nature, vol. 464, no. 7287, pp. 431-435, 2010.

[66] S. J. Heidorn, C. Milagre, S. Whittaker et al., "Kinasedead BRAF and oncogenic RAS cooperate to drive tumor progression through CRAF," Cell, vol. 140, no. 2, pp. 209$221,2010$.

[67] A. Duffy and S. Kummar, "Targeting mitogen-activated protein kinase kinase (MEK) in solid tumors," Targeted Oncology, vol. 4, no. 4, pp. 267-273, 2009.

[68] S. Daouti, B. Higgins, K. Kolinsky et al., "Preclinical in vivo evaluation of efficacy, pharmacokinetics, and pharmacodynamics of a novel MEK1/2 kinase inhibitor RO5068760 in multiple tumor models," Molecular Cancer Therapeutics, vol. 9, no. 1, pp. 134-144, 2010.

[69] J. Y. Yoon, K. H. Koo, and K. Y. Choi, "MEK1/2 inhibitors AS703026 and AZD6244 may be potential therapies for KRAS mutated colorectal cancer that is resistant to EGFR monoclonal antibody therapy," Cancer Research, vol. 71, no. 2, pp. 445-453, 2011.

[70] C. Montagut and J. Settleman, "Targeting the RAF-MEKERK pathway in cancer therapy," Cancer Letters, vol. 283, no. 2, pp. 125-134, 2009.

[71] D. B. Solit, L. A. Garraway, C. A. Pratilas et al., "BRAF mutation predicts sensitivity to MEK inhibition," Nature, vol. 439, no. 7074, pp. 358-362, 2006.

[72] R. B. Corcoran, D. Dias-Santagata, K. Bergethon, A. J. Iafrate, J. Settleman, and J. A. Engelman, "BRAF gene amplification can promote acquired resistance to MEK inhibitors in cancer cells harboring the BRAF V600E mutation," Science Signaling, vol. 3, no. 149, article ra84, 2010.

[73] A. Di Cristofano and P. P. Pandolfi, "The multiple roles of PTEN in tumor suppression," Cell, vol. 100, no. 4, pp. 387390, 2000.

[74] H. K. Roy, B. F. Olusola, D. L. Clemens et al., "AKT protooncogene overexpression is an early event during sporadic colon carcinogenesis," Carcinogenesis, vol. 23, no. 1, pp. 201205, 2002.
[75] M. Jhawer, S. Goel, A. J. Wilson et al., "PIK3CA mutation/PTEN expression status predicts response of colon cancer cells to the epidermal growth factor receptor inhibitor cetuximab," Cancer Research, vol. 68, no. 6, pp. 1953-1961, 2008.

[76] Y. Samuels, Z. Wang, A. Bardelli et al., "High frequency of mutations of the PIK3CA gene in human cancers," Science, vol. 304, no. 5670, p. 554, 2004.

[77] A. Sood, D. McClain, R. Seetharam et al., "Beyond KRAS: the quest for novel genetic markers predictive for response to anti-epidermal growth factor receptor (EGFR) therapy in patients with metastatic colorectal cancer (mCRC)," Journal of Clinical Oncology, vol. 28, no. 15, supplement, 2010, ASCO Annual Meeting, abstract no. 3567.

[78] D. W. Parsons, T. L. Wang, Y. Samuels et al., "Colorectal cancer: mutations in a signalling pathway," Nature, vol. 436, no. 7052, p. 792, 2005.

[79] C. A. Townsley, P. Major, L. L. Siu et al., "Phase II study of erlotinib (OSI-774) in patients with metastatic colorectal cancer," British Journal of Cancer, vol. 94, no. 8, pp. 11361143, 2006.

[80] M. L. Rothenberg, B. LaFleur, D. E. Levy et al., "Randomized phase II trial of the clinical and biological effects of two dose levels of gefitinib in patients with recurrent colorectal adenocarcinoma," Journal of Clinical Oncology, vol. 23, no. 36, pp. 9265-9274, 2005.

[81] J. A. Meyerhardt, A. X. Zhu, P. C. Enzinger et al., "Phase II study of capecitabine, oxaliplatin, and erlotinib in previously treated patients with metastastic colorectal cancer," Journal of Clinical Oncology, vol. 24, no. 12, pp. 1892-1897, 2006.

[82] T. Kuo, C. D. Cho, J. Halsey et al., "Phase II study of gefitinib, fluorouracil, leucovorin, and oxaliplatin therapy in previously treated patients with metastatic colorectal cancer," Journal of Clinical Oncology, vol. 23, no. 24, pp. 5613-5619, 2005.

[83] M. G. Zampino, E. Magni, C. Massacesi et al., "First clinical experience of orally active epidermal growth factor receptor inhibitor combined with simplified FOLFOX6 as first-line treatment for metastatic colorectal cancer," Cancer, vol. 110, no. 4, pp. 752-758, 2007.

[84] A. J. Weickhardt, T. J. Price, N. Pavlakis et al., "DUX study: a phase II study of evaluating dual targeting of the EGFR using the combination of cetuximab and erlotinib in patients with chemotherapy refractory metastatic colorectal cancer," Journal of Clinical Oncology, vol. 28, no. 15, supplement, 2010, ASCO Annual Meeting Proceedings, abstract no. 3533.

[85] J. R. Tonra, D. S. Deevi, E. Corcoran et al., "Synergistic antitumor effects of combined epidermal growth factor receptor and vascular endothelial growth factor receptor-2 targeted therapy," Clinical Cancer Research, vol. 12, no. 7, pp. 2197-2207, 2006.

[86] N. C. Tebbutt, D. Kotasek, H. A. Burris et al., "Motesanib with or without panitumumab (pmab) plus FOLFIRI or FOLFOX for the treatment of metastatic colorectal cancer (mCRC)," in Proceedings of the ASCO Annual Meeting, 2010, abstract no. 3538 .

[87] S. Kopetz, J. Desai, E. Chan et al., "PLX4032 in metastatic colorectal cancer patients with mutant BRAF tumors," Journal of Clinical Oncology, vol. 28, no. 15, supplement, 2010, abstract no. 3534.

[88] C. Eng, J. Tabernero, E. Nowara et al., "Panitumumab (pmab) plus AMG 102 in patients (pts) with wild-type KRAS metastatic colorectal cancer (mCRC): updated safety 
results," Journal of Clinical Oncology, vol. 28, supplement, 2010, ASCO Annual Meeting, abstract no. e14083.

[89] M. Di Salvatore, A. Inno, A. Orlandi et al., "KRAS and BRAF mutational status and PTEN, cMET, and IGF1R expression as predictive markers of response to cetuximab plus chemotherapy in metastatic colorectal cancer (mCRC)," Journal of Clinical Oncology, vol. 28, supplement, 2010, ASCO Annual Meeting, abstract no. e14065.

[90] S. R. Alberts, D. J. Sargent, T. C. Smyrk et al., "Adjuvant mFOLFOX6 with or without cetuximab (Cmab) in KRAS wild-type (WT) patients (pts) with resected stage III colon cancer (CC): results from NCCTG Intergroup Phase III Trial N0147," Journal of Clinical Oncology, vol. 28, no. 15, supplement, 2010, ASCO Annual Meeting, abstract no. CRA3507.

[91] R. M. Goldberg, D. J. Sargent, and S. N. Thibodeau, "Adjuvant mFOLFOX6 plus or minus cetuximab (Cmab) in patients (pts) with KRAS mutant $(\mathrm{m})$ resected stage III colon cancer (CC): NCCTG Intergroup Phase III Trial N0147," Journal of Clinical Oncology, vol. 28, no. 15, supplement, 2010, ASCO Annual Meeting, abstract no. 3508.

[92] J. Giralt, M. de las Heras, L. Cerezo et al., "The expression of epidermal growth factor receptor results in a worse prognosis for patients with rectal cancer treated with preoperative radiotherapy: a multicenter, retrospective analysis," Radiotherapy and Oncology, vol. 74, no. 2, pp. 101-108, 2005.

[93] J. S. Kim, J. M. Kim, S. Li et al., "Epidermal growth factor receptor as a predictor of tumor downstaging in locally advanced rectal cancer patients treated with preoperative chemoradiotherapy," International Journal of Radiation Oncology Biology Physics, vol. 66, no. 1, pp. 195-200, 2006.

[94] K. Y. Chung, B. Minsky, D. Schrag et al., "Phase I trial of preoperative cetuximab with concurrent continuous infusion 5-fluorouracil and pelvic radiation in patients with localregionally advanced rectal cancer," Journal of Clinical Oncology, vol. 24, no. 18, supplement, 2006, abstract no. 3560.

[95] R. D. Hofheinz, K. Horisberger, C. Woernle et al., "Phase I trial of cetuximab in combination with capecitabine, weekly irinotecan, and radiotherapy as neoadjuvant therapy for rectal cancer," International Journal of Radiation Oncology Biology Physics, vol. 66, no. 5, pp. 1384-1390, 2006.

[96] J. P. Machiels, C. Sempoux, P. Scalliet et al., "Phase I/II study of preoperative cetuximab, capecitabine, and external beam radiotherapy in patients with rectal cancer," Annals of Oncology, vol. 18, no. 4, pp. 738-744, 2007.

[97] C. Rödel, D. Arnold, M. Hipp et al., "Phase I-II Trial of cetuximab, capecitabine, oxaliplatin, and radiotherapy as preoperative treatment in rectal cancer," International Journal of Radiation Oncology Biology Physics, vol. 70, no. 4, pp. 1081-1086, 2008.

[98] K. Horisberger, A. Treschl, S. Mai et al., "Cetuximab in combination with capecitabine, irinotecan, and radiotherapy for patients with locally advanced rectal cancer: results of a phase II MARGIT trial," International Journal of Radiation Oncology Biology Physics, vol. 74, no. 5, pp. 1487-1493, 2009.

[99] F. Bertolini, S. Chiara, C. Bengala et al., "Neoadjuvant treatment with single-agent cetuximab followed by 5 -FU, cetuximab, and pelvic radiotherapy: a phase II study in locally advanced rectal cancer," International Journal of Radiation Oncology Biology Physics, vol. 73, no. 2, pp. 466472, 2009.

[100] V. Velenik, J. Ocvirk, I. Oblak, and F. Anderluh, "A phase II study of cetuximab, capecitabine and radiotherapy in neoadjuvant treatment of patients with locally advanced resectable rectal cancer," European Journal of Surgical Oncology, vol. 36, no. 3, pp. 244-250, 2010.

[101] C. Bengala, S. Bettelli, F. Bertolini et al., "Epidermal growth factor receptor gene copy number, K-ras mutation and pathological response to preoperative cetuximab, 5-FU and radiation therapy in locally advanced rectal cancer," Annals of Oncology, vol. 20, no. 3, pp. 469-474, 2009.

[102] A. Debucquoy, K. Haustermans, A. Daemen et al., "Molecular response to cetuximab and efficacy of preoperative cetuximab-based chemoradiation in rectal cancer," Journal of Clinical Oncology, vol. 27, no. 17, pp. 2751-2757, 2009.

[103] K. J. Williams, B. A. Telfer, I. J. Stratford, and S. R. Wedge, "ZD1839 ('Iressa'), a specific oral epidermal growth factor receptor-tyrosine kinase inhibitor, potentiates radiotherapy in a human colorectal cancer xenograft model," British Journal of Cancer, vol. 86, no. 7, pp. 1157-1161, 2002.

[104] V. Valentini, A. De Paoli, M. A. Gambacorta et al., "Infusional 5-fluorouracil and ZD1839 (Gefitinib-Iressa) in combination with preoperative radiotherapy in patients with locally advanced rectal cancer: a phase I and II trial (1839IL/0092)," International Journal of Radiation Oncology Biology Physics, vol. 72, no. 3, pp. 644-649, 2008.

[105] L. S. Blaszkowsky, T. S. Hong, A. X. Zhu et al., "A phase I/II study of bevacizumab, erlotinib, and 5-fluorouracil with concurrent external beam radiation therapy in locally advanced rectal cancer," Journal of Clinical Oncology, vol. 27, no. 15, supplement, p. 194S, 2009, abstract no. 4106. 


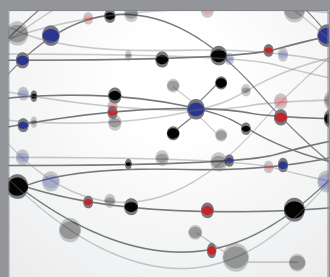

The Scientific World Journal
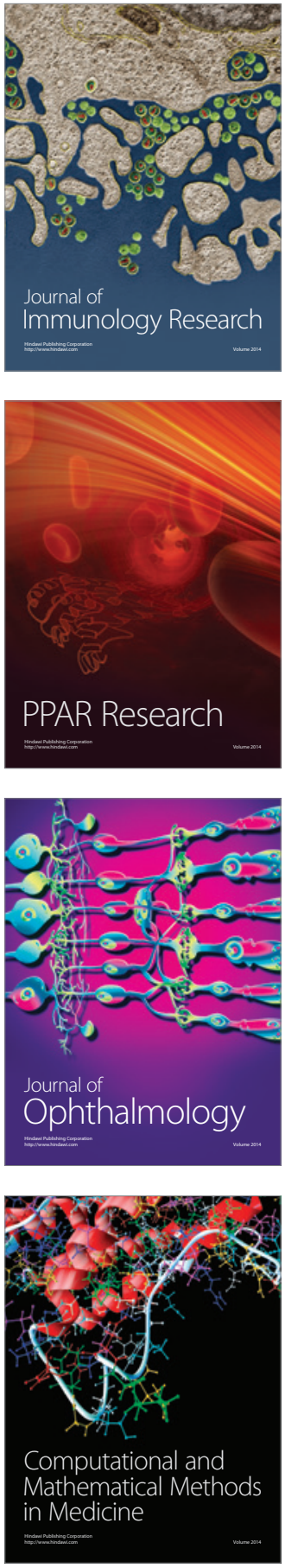

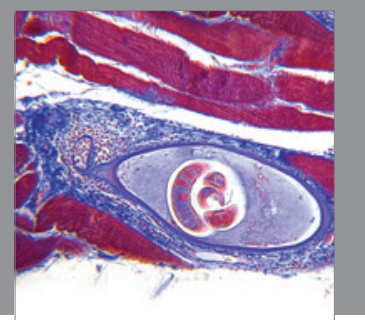

Gastroenterology

Research and Practice
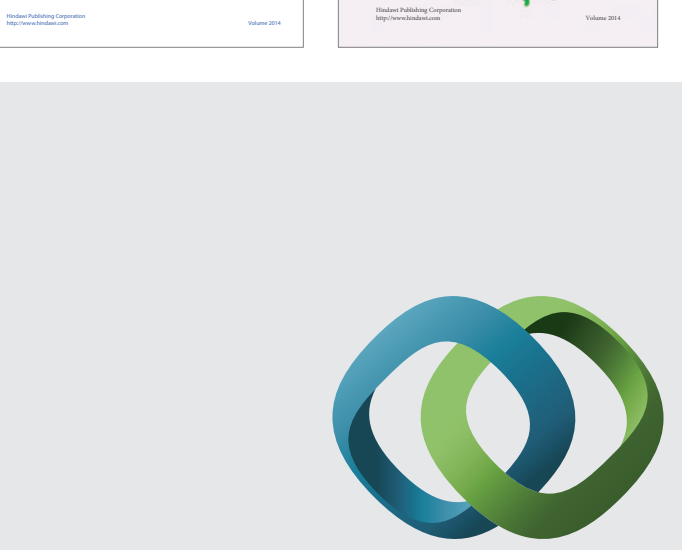

\section{Hindawi}

Submit your manuscripts at

http://www.hindawi.com
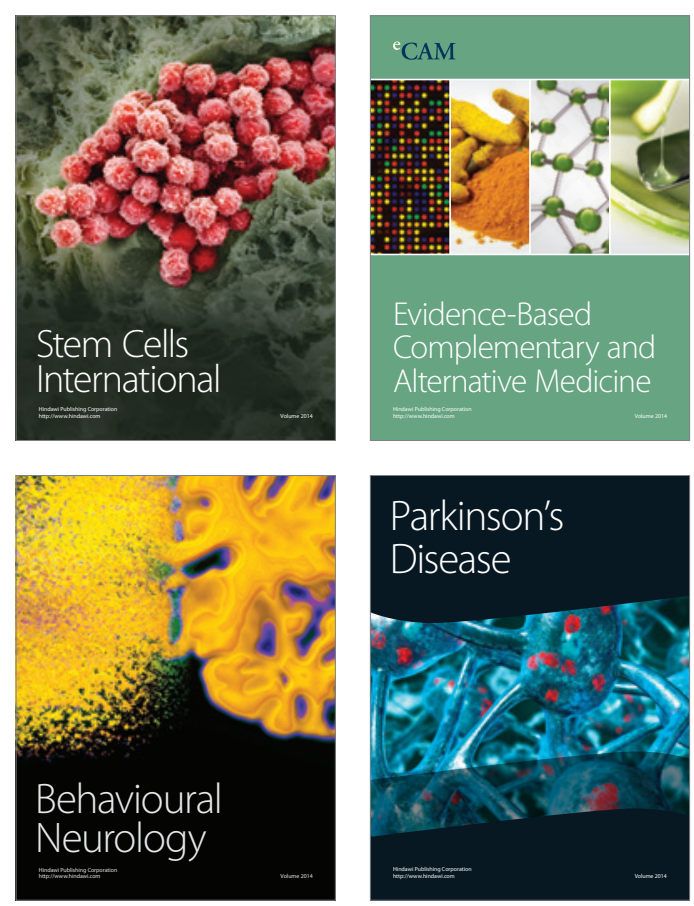

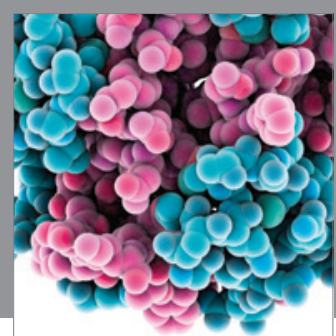

Journal of
Diabetes Research

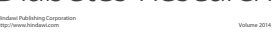

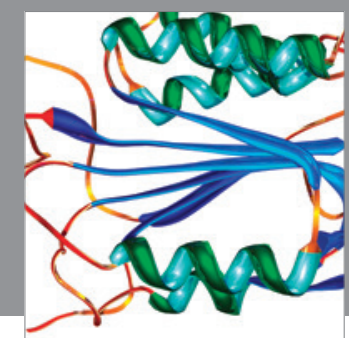

Disease Markers
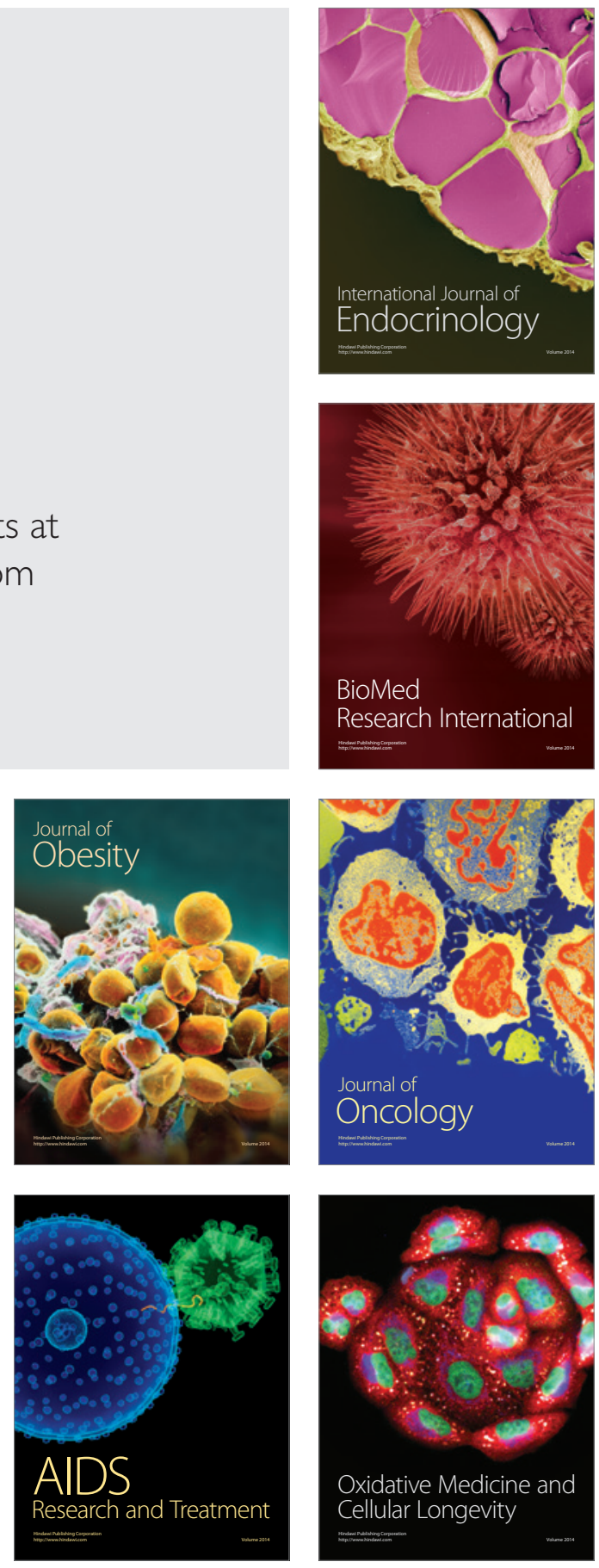